\author{
Piotr Arkuszewski*, Łukasz Antoszczyk** \\ Magdalena Mazurek-Wardak ${ }^{* * *}$, Zbigniew Wardak ${ }^{* * * *}$
}

\title{
ŚMIERĆ SERGIUSZA JESIENINA - SAMOBÓJSTWO CZY ZABÓJSTWO UPOZOROWANE NA SAMOBÓJSTWO? ANALIZA WYBRANYCH OKOLICZNOŚCI ZGONU I OBRAŻEŃ CIAŁA ${ }^{1}$
}

Streszczenie. Artykuł zawiera rozważania dotyczące wybranych, kluczowych okoliczności śmierci rosyjskiego poety Sergiusza Jesienina oraz stwierdzonych u niego po śmierci obrażeń ciała. Autorzy skupili się na najważniejszych dostępnych dziś informacjach, które wskazują, że faktyczna przyczyna zgonu poety mogła być inna niż oficjalna. Pewne fakty podają bowiem w wątpliwość samobójcze zawiśnięcie w pętli, a inne z kolei sugerują możliwość dokonania zabójstwa $\mathrm{z}$ upozorowaniem go na samobójstwo.

Słowa kluczowe: Sergiusz Jesienin, upozorowanie zabójstwa na samobójstwo, powieszenie, zadzierzgnięcie, włamanie kości czaszki.

Okoliczności śmierci rosyjskiego poety Sergiusza Jesienina (1895-1925) do dziś budzą kontrowersje i są tematem dyskusji. Oficjalna przyczyna jego zgonu, za którą uznano samobójcze zawiśnięcie w pętli, jest przez wiele osób podawana w wątpliwość. Istnieją bowiem przesłanki wskazujące na możliwość dokonania zabójstwa tej osoby z upozorowaniem go na samobójstwo. Autorzy artykułu przedstawiają swoje wnioski na temat przyczyny i okoliczności zgonu Sergiusza Jesienina, sformułowane na podstawie weryfikacji wybranych, najistotniejszych informacji dotyczących sprawy. Są nimi ślady na ciele zmarłego widoczne na pośmiertnych zdjęciach ciała poety. Dodatkowo dokonano oceny informacji

* Uniwersytet Medyczny w Łodzi, Wydział Lekarski, Katedra Endokrynologii, Zakład Chirurgii Doświadczalnej, arkusz@op.pl.

** Uniwersytet Medyczny w Łodzi, Wydział Lekarski, Międzywydziałowa Katedra Patomorfologii, Zakład Patomorfologii, uakanto@gmail.com.

*** Uniwersytet Łódzki, Wydział Prawa i Administracji, Katedra Postępowania Karnego i Kryminalistyki, Zakład Postępowania Karnego, prokurator Prokuratury Rejonowej Łódź-Polesie, magdalencja01@outlook.com.

${ }^{* * * *}$ Uniwersytet Łódzki, Wydział Prawa i Administracji, Katedra Postępowania Karnego i Kryminalistyki, Zakład Kryminalistyki, zbigniew.wardak@gmail.com.

${ }^{1}$ Niniejszy artykuł powstał dzięki inspiracji zaczerpniętej z przedstawienia teatralnego Spowiedź chuligana, zrealizowanego w Instytucie Teatralnym im. Mieczysława Hertza w Lodzi w reżyserii Jacka Orłowskiego. 
zawartych $\mathrm{w}$ protokole sekcji zwłok i skonfrontowano je $\mathrm{z}$ oficjalną przyczyną śmierci oraz wynikającym z niej mechanizmem, który uznano za prowadzący do zgonu.

Wśród zwolenników wersji, zgodnie z którą doszło do zabójstwa Sergiusza Jesienina z upozorowaniem go na samobójstwo, znajdują się G. Ojcewicz, R. Włodarczyk i D. Zajdel (Ojcewicz i in. 2009, 542; Włodarczyk i in. 2011, 70; Ojcewicz 2011, 248-249). Według nich przyczyną zgonu było zbrodnicze zadzierzgnięcie pętli na szyi, przy czym czynność ta miała być poprzedzona silnym uderzeniem w głowę - zdaniem autorów zadanym kolbą rewolweru Nagant - zaś już po śmierci miały zostać oddane w głowę strzały z broni palnej (Ojcewicz i in. 2009, 70; Włodarczyk i in. 2011, 70; Ojcewicz 2011, 248-249). Jako sprawców zbrodni, do której miało dojść w nocy z 27 na 28 grudnia 1925 r., wskazują funkcjonariuszy OGPU (Zjednoczonego Państwowego Zarządu Politycznego, jednej ze służb specjalnych ZSRR - przyp. aut.). Cała sytuacja miała rozpocząć się w apartamencie Hotelu Angleterre w Leningradzie. Śmierć Jesienina miała nastąpić $\mathrm{w}$ sąsiadującym $\mathrm{z}$ hotelem areszcie OGPU, zaś po przeniesieniu zwłok z powrotem do hotelowego apartamentu miało dojść do upozorowania samobójstwa przez powieszenie.

Sekcję zwłok Sergiusza Jesienina wykonał w dniu 29 grudnia 1925 r. w Szpitalu Obuchowskiego w Leningradzie lekarz Aleksander Gilarewski, a informacje o wykonanych czynnościach i ustaleniach zawarł w protokole sekcji zwłok ${ }^{2}$. Przyczyna śmierci została określona $\mathrm{w}$ tym protokole $\mathrm{w}$ następującym zapisie: „Na podstawie danych z sekcji zwłok należy stwierdzić, że śmierć Jesienina została spowodowana asfiksją (uduszeniem gwałtownym - przyp. aut.), do której doszło w wyniku ucisku na drogi oddechowe przy powieszeniu". W stwierdzeniu tym nie wskazano, czy powieszenie miało charakter samobójczy, czy było jednak spowodowane zbrodniczym działaniem innych osób, co jest zbieżne z powszechnie przyjętymi, współczesnymi zasadami formułowania wniosków w tego typu przypadkach przy braku bliższych informacji na temat okoliczności zgonu.

Na pośmiertnych zdjęciach ciała Sergiusza Jesienina uwagę zwraca zniekształcenie zarysów głowy w okolicy czołowej o wyglądzie przypominającym włamanie kości czaszki. Jest ono widoczne na zdjęciu, wykonanym w apartamencie hotelowym, w którym znaleziono ciało Sergiusza Jesienina (fot. 1).

Włamanie kości czaszki jest jednym z rodzajów złamania kości czaszki. Powstaje w wyniku urazu narzędziem o względnie niedużej powierzchni i polega na wydzieleniu i przemieszczeniu odłamu albo odłamów w kierunku wnętrza czaszki, a odłam może odwzorowywać kształt powierzchni działającego narzędzia (Jakliński i in. 1983, 91; Raszeja i in. 1993, 93). Ponadto włamanie kości czaszki pozwala ustalić miejsce zadziałania urazu (Jakliński i in. 1983, 91;

\footnotetext{
${ }^{2}$ https://ru.wikisource.org/wiki/Акт_патологоанатомического_вскрытия_тела_Есенина [dostęp 12.06.2017].
} 


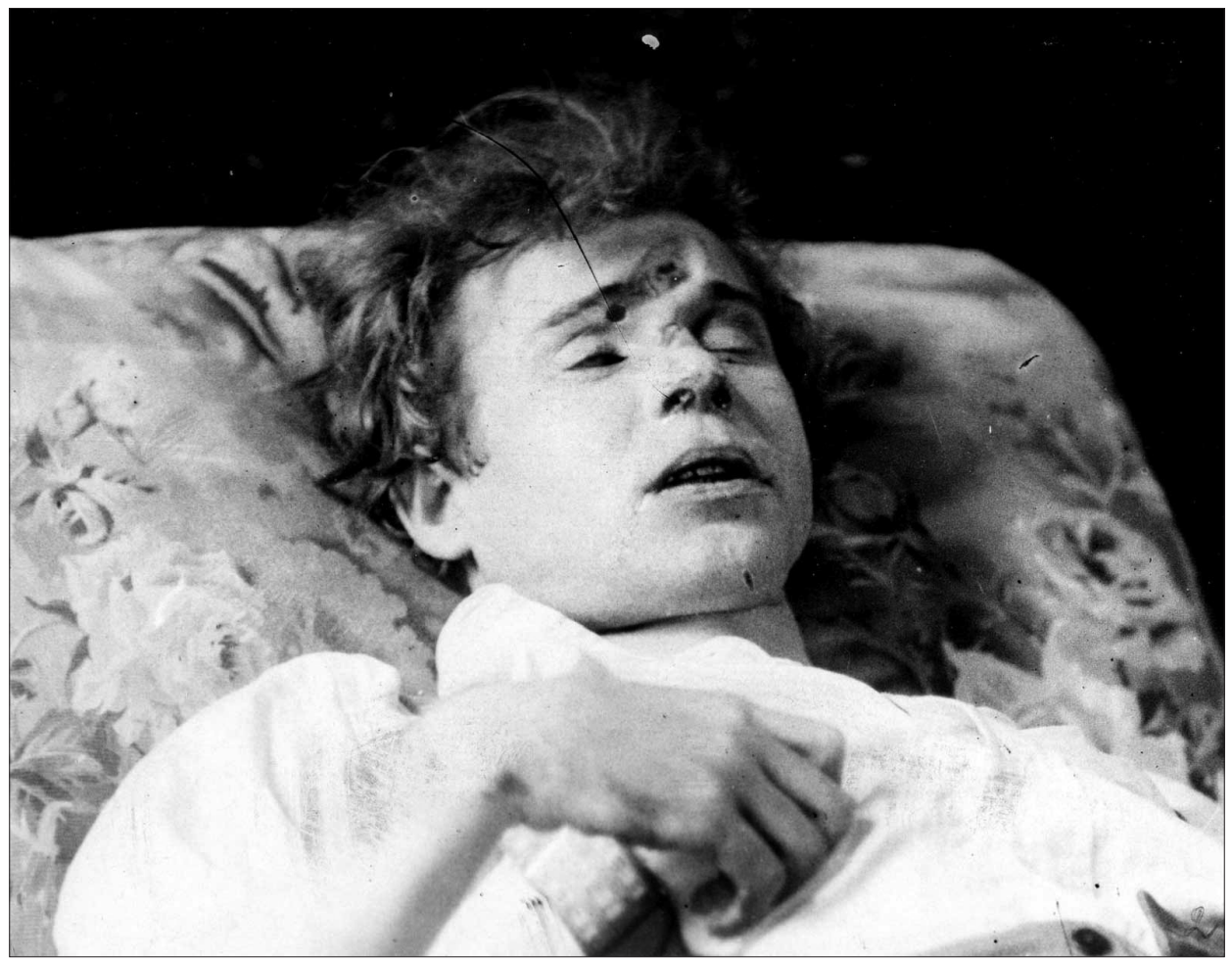

Fot. 1. Pośmiertne zdjęcie Sergiusza Jesienina przedstawiające zniekształcenie czaszki w okolicy czołowej

Źródło: www.esenin.ru (autor zdjęcia: Moisiej Nappelbaum)

Raszeja i in. 1993, 93; Teresiński 2002). Wykonujący sekcję patolog Aleksander Gilarewski opisał wspomniane zniekształcenie zarysów głowy w taki sposób: „Na środku czoła, nad grzbietem nosa, wklęsła bruzda długości ok. $4 \mathrm{~cm}$ i szerokości 1,5 cm”. Interesujący jest też kolejny fragment: „Kości czaszki całe, pod płatem skóry, w miejscu wklęsłej bruzdy w okolicy czoła obecne jest niewielkie podbiegnięcie krwawe". Obducent odniósł się także do możliwych okoliczności powstania tego śladu urazu, wypowiadając się w powyższej kwestii następująco: „Wgniecenie na czole mogło pojawić się z powodu ucisku przy powieszeniu”. Teoretycznie było to możliwe. W czasie sekcji zwłok osób powieszonych w pętli nieraz stwierdza się obrażenia w postaci podbiegnięć krwawych, otarć naskórka i ran, które nie muszą być wynikiem przestępnego działania innych osób, lecz mogą powstać $\mathrm{w}$ trakcie drgawek podczas agonii, w następstwie których ciało uderza o różne przedmioty (Jakliński i in. 1983, 153). Wskazani autorzy negują możliwość powstania włamania kości czaszki u Sergiusza Jesienina wskutek uderzenia o rurę grzewczą (Ojcewicz i in. 2009, 106). Argumentują to stwierdzenie tym, że rura ma zupełnie inny kształt, a - jako że włamanie kości czaszki 
ma odwzorowywać kształt działającego narzędzia - kształt włamania powstałego od uderzenia o rurę grzewczą powinien być odmienny niż na zdjęciu. Jest to w pełni słuszne spostrzeżenie, gdyż włamanie kości czaszki powstałe w takich okolicznościach teoretycznie powinno mieć dwie względnie równe i równoległe do siebie krawędzie, a także nie powinno posiadać jednolitych, ciągłych granic na całym obwodzie. Autorzy ci wykonali zresztą eksperyment procesowy, który nakazuje co najmniej podać w wątpliwość wersję o powstaniu tego obrażenia w wyniku uderzenia w rurę (Ojcewicz i in. 2009, 106-107). Na pośmiertnym zdjęciu Sergiusza Jesienina (fot. 1) wyraźnie widać bowiem, że zniekształcenie zarysów głowy nie posiada równych i równoległych do siebie krawędzi. W ocenie autorów niniejszej pracy jego kształt przypomina wydłużoną kroplę, z całą pewnością jest wklęsłe i najprawdopodobniej jest związane ze złamaniem kości z przemieszczeniem odłamów w kierunku jamy czaszki, czyli z włamaniem. Taki wygląd nasuwa podejrzenie urazu narzędziem tępym bądź tępokrawędzistym, innym niż rura grzewcza oraz większej siły urazu niż spowodowana uderzeniem o rurę grzewczą w przebiegu agonalnych drgawek, bowiem obecność włamania kości czaszki świadczy o dużej prędkości godzącego narzędzia i dużej energii urazu (Teresiński 2002). Nie można ponadto wykluczyć, że w obrębie zniekształcenia zarysów głowy znajdowała się - tuż przy prawej brwi - rana tłuczona powłok głowy. Wszystkie przytoczone informacje kierują rozważania na temat okoliczności powstania zniekształcenia zarysów głowy ku mechanizmowi innemu niż wskazany w protokole sekcji zwłok, na przykład ku wersji podanej przez powoływanych autorów, według której włamanie kości czaszki zostało spowodowane uderzeniem kolbą rewolweru Nagant (Ojcewicz i in. 2009, 193; Ojcewicz 2014, 248). Taki mechanizm powstania obrażenia jest możliwy i na pewno dużo bardziej prawdopodobny niż mechanizm uderzenia o rurę grzewczą podczas agonalnych drgawek.

Zdaniem autorów niniejszej pracy zastrzeżenia co do zgodności z prawdą budzi fragment protokołu sekcji zwłok, w którym lekarz opisał podbiegnięcie krwawe zlokalizowane pod skórą w okolicy odpowiadającej zniekształceniu kości czaszki o wyglądzie włamania i stwierdził przy tym, że kości czaszki są całe. Ponadto, gdyby nastąpiło uderzenie głową o rurę już po zawiśnięciu w pętli, to nie powinno powstać podbiegnięcie krwawe w tkankach miękkich, ponieważ przy powieszeniu typowym, wobec niemal natychmiastowego zamknięcia dopływu krwi tętniczej do głowy, w wyniku zamknięcia światła tętnic szyjnych i kręgowych przez pętlę, dochodzi do błyskawicznego zatrzymania krążenia krwi powyżej bruzdy i dodatkowo do niemal natychmiastowej utraty przytomności (Jakliński i in. 1983, 146; Raszeja i in. 1993, 129-130). Skutkiem tego są bardzo słabo wyrażone bądź w ogóle nieobecne cechy przyżyciowego działania pętli w obrębie bruzdy lub powyżej niej, takie jak sinica skóry twarzy i wybroczyny krwawe podspojówkowe (Jakliński $i$ in. 1983, 152; Raszeja i in. 1993, 129-130). Tymczasem podbiegnięcia krwawe są jedną z cech przyżyciowości obrażeń, ponieważ powstają wskutek przerwania ciągłości naczyń krwionośnych przy zachowanym krążeniu krwi pod dostatecznym 
ciśnieniem (Jakliński i in. 1983, 80-81). Co prawda znane jest zjawisko powstawania pośmiertnych podbiegnięć krwawych, a więc już przy braku krążenia krwi, jednak nie w obszarze ciała, w którym doszło do uprzedniego „odcięcia” dopływu krwi tętniczej jeszcze za życia (Barzdo i in. 2010, 84-87). Kolejnym fragmentem protokołu sekcji zwłok, którego treść nie wykazuje korelacji i zbieżności z oficjalną wersją zdarzenia, jest poniższy zapis: „Mózg waży 1920 g. [...] Tkanka mózgowa na przekroju lśniąca, przy przekrawaniu szybko pokrywa się kropelkami krwi”. Przy powieszeniu typowym, wobec wspomnianego już odcięcia dopływu krwi tętniczej, mózg jest blady i niedokrwiony (Jakliński i in. 1983, 153). Tymczasem cytowany opis świadczy o znacznym przekrwieniu i o bardzo dużym, niezwykle rzadko spotykanym obrzęku mózgu. Przemawia za tym przede wszystkim ciężar mózgu wynoszący $1920 \mathrm{~g}$ - sporadycznie stwierdzany podczas sekcji zwłok. Tak znacznego stopnia przekrwienie i obrzęk mózgu mogą wynikać z zastoju krwi w obrębie głowy w wyniku zamknięcia światła naczyń żylnych przy niecałkowitym zamknięciu dopływu krwi do głowy i są charakterystyczne dla zadzierzgnięcia pętli na szyi i zadławienia, ale nie dla typowego powieszenia (Jakliński i in. 1983, 156, 158-159; Raszeja i in. 1993, 130, 133, 134).

Innym elementem protokołu sekcji zwłok, podważającym jego wiarygodność, jest taki oto opis bruzdy na szyi zmarłego: „Na szyi nad krtanią czerwona bruzda, przebiegająca od lewej strony do góry i kończąca się w pobliżu małżowiny usznej z przodu. Z prawej strony bruzda przebiega nieco do góry, ku okolicy potylicznej, gdzie kończy się. Bruzda szerokości gęsiego pióra”. Taki przebieg bruzdy jest charakterystyczny dla bruzdy wisielczej. W przypadku powieszenia typowego bruzda na przedniej powierzchni szyi przebiega poprzecznie, pomiędzy kością gnykową a krtanią, natomiast ramiona bruzdy na bocznych powierzchniach szyi wznoszą się i łączą się na karku - tzw. „bruzda zamknięta” albo giną w obrębie skóry owłosionej głowy w okolicy potylicznej - tzw. „bruzda otwarta”. Intensywność bruzdy jest największa po stronie przeciwległej do punktu zawieszenia pętli na szyi, a więc w przypadku typowego powieszenia - na przedniej powierzchni szyi (Jakliński i in. 1983, 148; Raszeja i in. 1993, 128, 130). Tymczasem przy zadzierzgnięciu bruzda wykazuje zwykle przebieg okrężny, w ogólności na jednakowym poziomie, obejmuje pełny obwód szyi i nie posiada ramion, zaś intensywność bruzdy jest mniej więcej jednakowa na całej jej długości, ewentualnie jest ona lepiej widoczna w okolicy karku (Raszeja i in. 1993, 133; Jakliński i in. 1983, 156).

Bruzda na szyi Sergiusza Jesienina jest dobrze widoczna na zdjęciu wykonanym w prosektorium Szpitala Obuchowskiego w Leningradzie, już po przeprowadzeniu sekcji zwłok (fot. 2 i fot. 2a).

Uwidoczniony na tej fotografii fragment bruzdy po prawej stronie szyi przebiega bardziej poziomo, nie kieruje się ku okolicy potylicznej ani nie kończy w pobliżu małżowiny usznej, lecz przechodzi na powierzchnię karku, ma więc raczej wygląd typowy dla bruzdy powstałej w wyniku zadzierzgnięcia pętli na szyi. W przypadku powieszenia taki przebieg bruzdy może wystąpić jedynie przy powieszeniu 


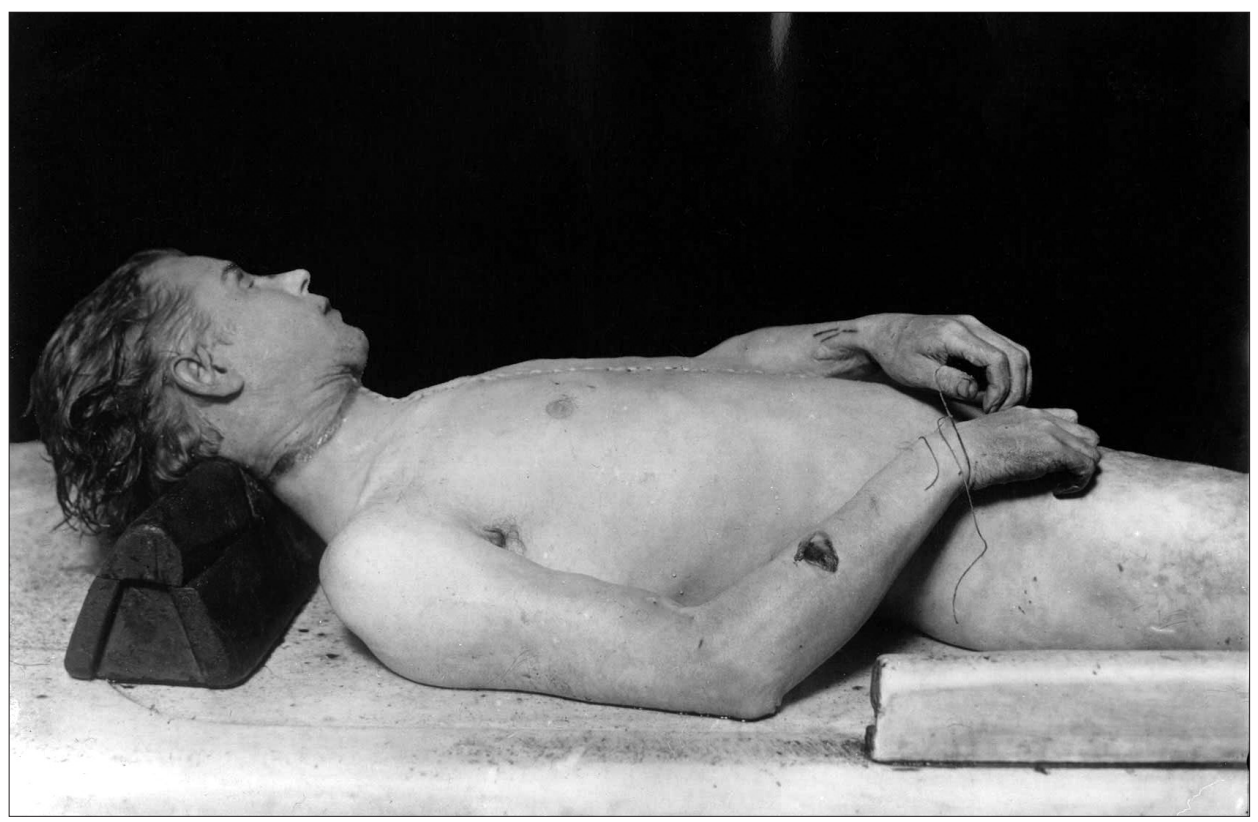

Fot. 2. Zdjęcie ciała Sergiusza Jesienina wykonane po zakończeniu sekcji zwłok

Źródło: www.esenin.ru (autor nieznany)

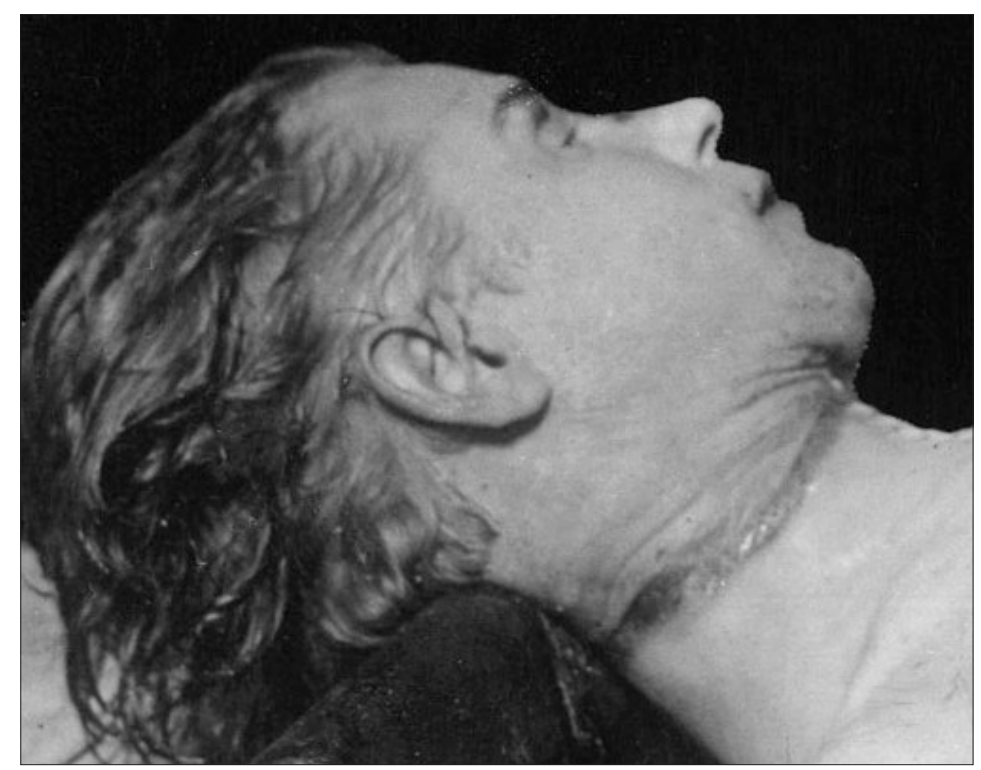

Fot. 2a. Fragment tego samego zdjęcia ukazujący z bliska bruzdę na szyi Sergiusza Jesienina

Źródło: www.esenin.ru (autor nieznany) 
nietypowym w pozycji leżącej, ale na pewno nie w pozycji wiszącej (Jakliński i in. 1983, 151). Informacje te stanowią bardzo poważną przesłankę tego, że przyczyną zgonu Sergiusza Jesienina mogło być zadzierzgnięcie pętli na szyi, a nie zawiśnięcie w pętli. Zadzierzgnięcie - w przeciwieństwie do powieszenia - prawie zawsze jest wynikiem zbrodniczego działania osób trzecich, a nie samobójstwem (Jakliński i in. 1983, 154-155; Raszeja i in. 1993, 131, 133). Zdaniem autorów niniejszej pracy, widniejąca na omawianym zdjęciu bruzda jest tą, o której mowa w protokole sekcyjnym, a której opis sugeruje, że jest to bruzda wisielcza. Co prawda przywoływani autorzy wskazują na obecność bruzdy wisielczej przy jednoczesnej obecności bruzdy od zadzierzgnięcia, ale należy tu mieć na uwadze możliwość istnienia tzw. „bruzd rzekomych”, które powstają w następstwie ucisku na szyję przez ciasną odzież lub w wyniku odpowiedniego uformowania fałdów skórnych, przeważnie w zwłokach ludzi otyłych i małych dzieci, a także w zwłokach objętych rozkładem gnilnym (Jakliński i in. 1983, 152). Według autorów niniejszego artykułu na omawianym zdjęciu nie widać bruzdy wisielczej, a wygląd widocznego fragmentu bruzdy nie jest zbieżny z jej opisem zawartym w protokole sekcji. W miejscu, gdzie w świetle opisu powinna być widoczna bruzda wisielcza, mogą występować - i to tylko odcinkowo - fałdy skóry układające się w sposób imitujący wygląd bruzdy wisielczej. Niezrozumiałe byłoby opisanie ledwo widocznej bruzdy wisielczej, a jednocześnie pominięcie dużo bardziej wyraźnie zaznaczonej bruzdy o wyglądzie bruzdy po zadzierzgnięciu. Jeśli nawet bruzda wisielcza była obecna na szyi, to była bardzo dyskretna, co wskazywałoby na zaciśnięcie pętli na szyi z mniejszą siłą niż w przypadku bruzdy sugerującej zadzierzgnięcie. Różnicowanie mechanizmu uduszenia w tym przypadku utrudnia brak danych o ewentualnych obrażeniach wewnętrznych szyi. Ponadto zaskakuje odniesienie szerokości bruzdy do gęsiego pióra, zamiast do powszechnie stosowanych jednostek metrycznych. Jest to tym bardziej dziwne w kontekście podawania wymiarów innych obrażeń stwierdzonych na ciele Sergiusza Jesienina właśnie w jednostkach metrycznych. Próbę wyjaśnienia tej rozbieżności podjęli powoływani autorzy, wskazując na ,grę słów” zastosowaną przez autora protokołu sekcji zwłok w celu ukierunkowania podejrzeń co do przyczynienia się funkcjonariuszy OGPU do śmierci Sergiusza Jesienina (Ojcewicz i in. 2009, 132-133).

$\mathrm{Na}$ innym zdjęciu przedstawiającym zwłoki Sergiusza Jesienina widoczne jest dosyć charakterystyczne obrażenie, które nie zostało opisane w protokole sekcji zwłok (fot. 3).

Na tylnej powierzchni prawego przedramienia w części bliższej widoczna jest rana o wyglądzie rany dartej. Nie spowodowała ona zgonu ani też nie wskazuje na mechanizm śmierci. Niemniej jednak rana darta powstaje w dosyć specyficzny sposób. Charakteryzuje się ona płatowym oddzieleniem skóry od podłoża na jednym z brzegów rany, co jest skutkiem silnego urazu, do którego dochodzi w następstwie skośnego bądź stycznego do powierzchni skóry działania narzędzia tępego albo tępokrawędzistego (Jakliński i in. 1983, 89; Raszeja i in. 1993). 


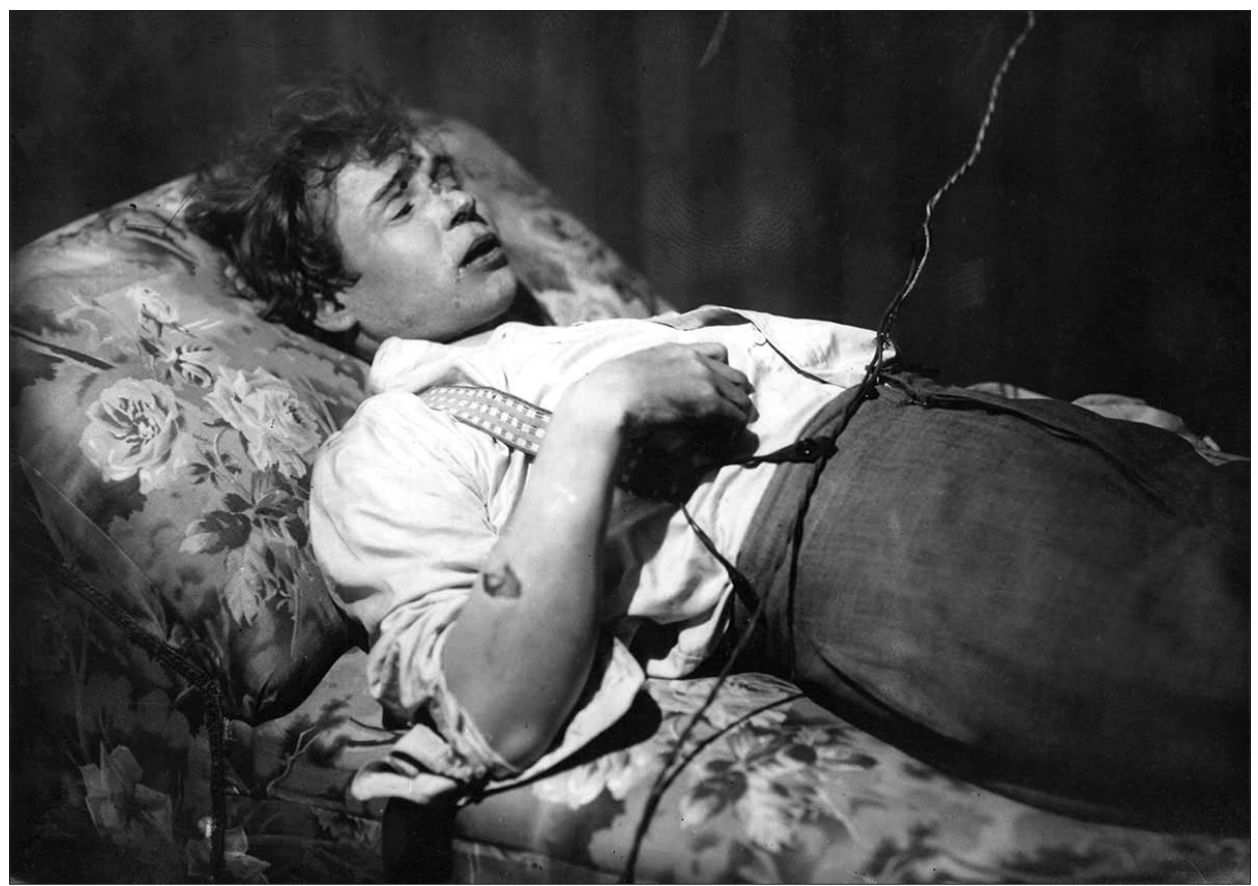

Fot. 3. Inne pośmiertne zdjęcie Sergiusza Jesienina, na którym widoczna jest rana darta na tylnej powierzchni prawego przedramienia

Źródło: www.esenin.ru (autor zdjęcia: Moisiej Nappelbaum)

Kolejnymi fragmentami protokołu sekcji zwłok, których treść budzi dalsze wątpliwości co do okoliczności śmierci Sergiusza Jesienina, są następujące opisy ran ciętych kończyn górnych: „W 1/3 dolnej części prawego ramienia, na skórze, znajduje się rana o równych brzegach, długości $4 \mathrm{~cm}$. W 1/3 dolnej części lewego przedramienia obecna jest jedna rana, przebiegająca poziomo i trzy rany przebiegające pionowo - te rany mają długość ok. $3 \mathrm{~cm}$, równe brzegi, nie przekraczają grubości skóry". W opisach tych nie ma jakiejkolwiek wzmianki o obecności podbiegnięć krwawych w otoczeniu ran, chociaż obducent podczas sekcji zwracał uwagę na tę cechę. Świadczy o tym opis podbiegnięcia krwawego w okolicy zniekształcenia kości czaszki o wyglądzie przypominającym włamanie. Opis ran ciętych w protokole, które według opinii posekcyjnej mogły zostać spowodowane przez Sergiusza Jesienina i nie miały związku ze zgonem, nie świadczy jednak o przyżyciowym powstaniu tych ran, a zatem nie wyklucza zadania ich już po śmierci poety. Jest to kolejny argument za podejrzeniem upozorowania ${ }^{3}$

${ }^{3}$ Odnośnie zjawiska pozoracji, ale o odmiennym charakterze, tzn. upozorowania przestępstwa bez uprzedniego czynu przestępczego lub po wcześniejszym dokonaniu przestępstwa dla zatarcia jego śladów i tym samym utrudniania oceny charakteru zdarzenia zob. szerzej Sygit (1985). 
zabójstwa na samobójstwo ${ }^{4} \mathrm{w}$ omawianym przypadku. Na podstawie fotografii, ze względu na brak wyraźnej bruzdy wisielczej, można nawet wątpić, czy w ogóle doszło do zawiśnięcia w pętli, niezależnie od tego, czy byłoby to samobójstwo czy jego upozorowanie.

Protokół sekcyjny i materiał fotograficzny nie tylko nie wyjaśnia, czy doszło do uduszenia przez zawiśnięcie czy też zadzierzgnięcie pętli na szyi, ale pozostawia też wątpliwości co do przyczyny zgonu. Są one związane przede wszystkim z omawianym śladem na głowie denata, który według opisu obducenta byłby jedynie ,wgnieceniem” tkanek miękkich z podbiegnięciem krwawym, którego powstanie bez towarzyszącego złamania kości czaszki jest mało przekonujące. Jeśli w rzeczywistości obrażenie to powstało od silnego urazu głowy ze złamaniem kości czaszki, to niewykluczone, że doprowadziło ono do zgonu, a przynajmniej świadczyłoby o użyciu znacznej przemocy fizycznej przed śmiercią.

Zdaniem powoływanych autorów w obrębie głowy Sergiusza Jesienina miały być obecne ślady o wyglądzie ran postrzałowych (Ojcewicz i in. 2009, 109-112; Włodarczyk i in. 2011, 70; Ojcewicz 2011, 244). Jeden z tych śladów miał znajdować się tuż powyżej prawego oka i jest widoczny na fot. 1 . W naszej ocenie nie można wykluczyć obecności takich ran, ale dostępne fotografie nie pozwalają na takie rozpoznanie i nie ma innych przesłanek za nim przemawiających - tę kwestię mogłaby rozstrzygnąć już tylko ekshumacja zwłok.

Wyjaśnienie wszystkich aspektów, w których istnieją wątpliwości co do faktycznej przyczyny śmierci Sergiusza Jesienina i które nakazują wątpić w oficjalną wersję zdarzenia, przekracza ramy niniejszego opracowania. Działania te zostały natomiast podjęte przez G. Ojcewicz, R. Włodarczyk i D. Zajdel, a na uwagę zasługuje zwłaszcza książka pt. Zabójstwo Sergiusza Jesienina. Po jej wydaniu autorzy nie ustali w dążeniach mających na celu wyjaśnienie okoliczności śmierci poety, a jeden z nich dokonał nowych ustaleń w powyższej kwestii (Ojcewicz 2011, 248-249).

Autorzy niniejszego artykułu pragną jedynie zwrócić uwagę na kluczowe rozbieżności pomiędzy zapisami w protokole sekcji zwłok Sergiusza Jesienina a stanem widocznym na zdjęciach pośmiertnych i przyjętą za oficjalną wersją wydarzeń, zgodnie z którą poeta ten popełnił samobójstwo przez zawiśnięcie w pętli. Ponadto można wyrazić merytoryczne zastrzeżenia zarówno co do samego sposobu przeprowadzenia sekcji zwłok, jak i treści protokołu posekcyjnego, m.in. do mało dokładnej preparatyki i oceny struktur szyi, braku badania na zawartość alkoholu we krwi zmarłego, niejasnego opisu bruzdy na szyi, niespójnego z jej obrazem na fotografiach, mało wiarygodnego opisu obrażenia głowy, być może z celowym pominięciem stwierdzenia obrażeń kości czaszki, braku opisu rany dartej prawego przedramienia i niezgodności opisu mózgu z obrazem sekcyjnym spotykanym przy powieszeniu typowym.

${ }^{4} \mathrm{~W}$ zakresie pozoracji samobójstwa w przypadku znalezienia wiszących zwłok zob. szerzej Hołyst (2002, 697-707). 
Powoływani autorzy idą w swoich wnioskach jeszcze dalej. Przykładowo wskazują na obecność wielu innych obrażeń ciała Sergiusza Jesienina, a także na pobicie poety i stosowanie tortur (Ojcewicz i in. 2009, 63-72, 105-112, 120-123; Włodarczyk i in. 2011, 68-70; Ojcewicz 2011, 242-244, 248-249). Jednocześnie zwracają uwagę na trudną sytuację, w jakiej znalazł się lekarz Aleksander Gilarewski w obliczu konieczności przeprowadzenia sekcji zwłok Sergiusza Jesienina i na to, że nie było możliwości sporządzenia przez niego odpowiadającego prawdzie protokołu posekcyjnego (Ojcewicz i in. 2009, 127; Ojcewicz 2014, 407). Podają również informacje, które miałyby tłumaczyć postępowanie bardzo doświadczonego lekarza i sposób, w jaki najpierw przeprowadził sekcję zwłok, a potem sporządził protokół z tych czynności (Ojcewicz i in. 2009, 127-133; Ojcewicz 2011, 246; Ojcewicz 2014, 407). Ponadto autorzy ci opisują różne inne działania mające na celu zatajenie prawdy przez osoby inne niż obducent, m.in. związane z przeróbkami w protokole sekcji zwłok (Ojcewicz i in. 2009, 128-129).

Wyjaśnienie tajemnicy śmierci Sergiusza Jesienina wymagałoby bezpośredniej oceny obrażeń na ciele zmarłego, co z oczywistych powodów jest już niewykonalne. Nawet ekshumacja zwłok pozostawiłaby wiele pytań bez odpowiedzi.

\section{BIBLIOGRAFIA}

Barzdo, Maciej, Leszek Żydek, Anna Smędra-Kaźmirska, Ewa Meissner, Stefan Szram, Jarosław Berent. 2010. „Pośmiertne podbiegnięcia krwawe”. Archiwum Medycyny Sądowej i Kryminologii 60 (2-3): 83-87. http://www.amsik.pl/archiwum/2-3_2010/2-3_10b.pdf [dostęp 12.06.2017].

Hołyst, Brunon. 2002. Suicydologia. Warszawa: LexisNexis.

Jakliński, Andrzej, Jan Kobiela, Kazimierz Jaegermann, Zdzisław Marek, Zofia Tomaszewska, Bożena Turowska. 1983. Medycyna sądowa. Podręcznik dla studentów medycyny. Warszawa: Państwowy Zakład Wydawnictw Lekarskich.

Ojcewicz, Grzegorz. 2011. „Najnowsza wersja okoliczności i przyczyny śmierci Sergiusza Jesienina: od zlecenia do ekshumacji”. Acta Neophilologica 13: 236-250.

Ojcewicz, Grzegorz. 2014. „Z filologii śledczej. O Aleksandrze Gilarewskim, obducencie zwłok Siergieja Jesienina - raz jeszcze". Studia Rossica Gedanensis 1: 391-408.

Ojcewicz, Grzegorz, Renata Włodarczyk, Dariusz Zajdel. 2009. Zabójstwo Sergiusza Jesienina. Zabójstwo Sergiusza Jesienina. Studium kryminalistyczno-historyczne. Szczytno: Wydawnictwo Wyższej Szkoły Policji.

Protokót sekcji zwłok Sergiusza Jesienina. https://ru.wikisource.org/wiki/Акт_патологоанатомического_вскрытия_тела_Есенина [dostęp 12.06.2017].

Raszeja, Stefan, Władysław Nasiłowski, Jan Markiewicz. 1993. Medycyna sądowa. Podręcznik dla studentów. Warszawa: Państwowy Zakład Wydawnictw Lekarskich.

Sygit, Bogusław. 1985. Zachowania pozorujace przestepstwa i ich zwalczanie. Studium z dziedziny kryminalistyki. Warszawa-Poznań: Państwowe Wydawnictwo Naukowe.

Teresiński, Grzegorz. 2002. „O ustalaniu okoliczności urazu głowy”. Archiwum Medycyny Sadowej $i$ Kryminologii 52 (2): 65-83. http://www.amsik.pl/index.php?option=com content\&task=view\&id=171 [dostęp 12.06.2017].

Włodarczyk, Renata, Grzegorz Ojcewicz. 2011. „Wybrane aspekty analizy okoliczności i przyczyny śmierci Sergiusza Jesienina”. Problemy Kryminalistyki 272 (2): 66-70. clk.policja.pl/ download/4/141172/005-wlodarczyk.pdf [dostęp 12.06.2017]. 
Piotr Arkuszewski, Lukasz Antoszczyk

Magdalena Mazurek-Wardak, Zbigniew Wardak

\title{
SERGEI YESENIN'S DEATH - A SUICIDE OR A MURDER STAGED TO LOOK LIKE A SUICIDE? AN ANALYSIS OF SOME SELECTED CIRCUMSTANCES OF THE DEATH AND INJURIES
}

\begin{abstract}
The article contains some consideration about selected, crucial circumstances of the death of the Russian poet Sergei Yesenin and it also concerns the injuries found in him during the post-mortem examination. The authors have focused on the most important and currently available information which indicates that the true cause of the poet's death might have been different from the official cause of death. Some facts discredit suicidal hanging and the others suggest a possibility of a murder staged to look like a suicide.
\end{abstract}

Keywords: Sergei Yesenin, staging a murder to look like a suicide, hanging, strangulation, skull bone infarction. 